Journal of Agricultural Sciences
(Tarim Bilimleri Dergisi)

\title{
Evaluation of some groundwater quality parameters using geostatistics in the urban coastal aquifer of Bosaso plain, Somalia
}

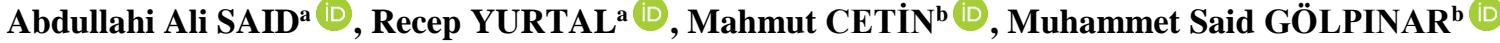 \\ ${ }^{a}$ Department of Civil Engineering, Faculty of Engineering, Çukurova University, 01330 Saricam, Adana, TURKEY \\ ${ }^{\boldsymbol{b}}$ Department of Agricultural Structures and Irrigation, Faculty of Agriculture, Çukurova University, 01330 Saricam, Adana, TURKEY
}

ARTICLE INFO

Research Article

Corresponding Author: Abdullahi Ali SAID, E-mail: abdulahi.said01@gmail.com

Received: 27 August 2019 / Revised: 25 November 2019 / Accepted: 02 December 2019 / Online: 18 January 2021

\section{ABSTRACT}

Groundwater is a major drinking water resource in arid coastal regions. The groundwater quality of Bosaso city experienced degradation due to rapid urbanization and industrialization. This study was carried out to delineate the spatial distribution of groundwater quality parameters and evaluate groundwater suitability for drinking and irrigation uses. The groundwater samples were collected from Bosaso Plain to determine the $\mathrm{pH}$, electrical conductivity (EC), total dissolved solids (TDS), and sodium and chloride concentrations. To categorize water quality for irrigation purposes, sodium adsorption ratio (SAR) was calculated Ordinary kriging procedure was performed in order to map the spatial distribution of groundwater quality parameters. The interpretation of laboratory analysis results revealed that the most of groundwater wells in the study area is unsafe for drinking purposes due to high salinity, except for the central area (Biyo Kulule). In terms of irrigation uses, the minor area may be under the risk of alkalinity or sodium hazard. However, all groundwater supply points are not suitable for irrigation due to the salinization risk and can be only used to irrigate high salttolerant crops. The final maps show that the groundwater quality decreases from southeast to the north of the plain. This indicates that the groundwater is probably subjected to the seawater intrusion. In this regard, the implementation of a groundwater monitoring program is necessary to achieve concrete results. Nevertheless, the most suitable groundwater quality is found to be at the central part of the Bosaso plain.

Keywords: Groundwater quality, Irrigation water, Geostatistics, GIS, Bosaso Plain, Somalia

(C) Ankara University, Faculty of Agriculture

\section{Introduction}

Coastal areas in arid and semi-arid regions highly depend on groundwater resources due to the lack of surface water. Bosaso is the major city of Puntland state, and groundwater is the main water source. The city faces degradation in water quality and water supply shortage due to the rapid population growth in recent years and effects of climate change and droughts (Said et al. 2019). Although groundwater monitoring is necessary for taking effective measures, currently there is no groundwater monitoring program in place. Proper management of groundwater resource is very important to meet the increasing demand for water. Furthermore, understanding the spatial distribution of groundwater quality helps authorities to develop optimal management strategy of groundwater resources in order to ensure sustainable development of the society.

Mapping groundwater quality parameters through using geostatistics has become well known. There are numerous studies on groundwater quality evaluation using geostatistical techniques all around the world (Nur et al. 2012; Shamsudduha 2007; Goovaerts et al. 2005; Zehtabian et al. 2013). Sarath Prasanth et al. (2012) conducted a study to assess the spatial distribution of groundwater quality in the coastal city of Alappuzha in India. The results revealed the groundwater is entirely suitable for drinking water supply. Additionally, it presents that the groundwater is appropriate for irrigation purposes excluding a few sites. Arslan (2012) used ordinary kriging procedures to analyze the spatial distribution of groundwater salinity in the Bafra plain of Turkey. Based on the research results, it was shown that groundwater salinity levels were in a decreasing trend behavior. Nas \& Berktay (2008) used geostatistical techniques to map and evaluate groundwater in Konya province in Turkey. The results revealed that the groundwater quality decreased from south to north. Although geostatistical techniques have been made widely applicable in the hydro-sciences all over the world since the early 1970s, literature review leads us to believe that application of kriging procedures to the water science needs to be further popularized in Somalia.

The objectives of the study are two-fold: a) to delineate the spatial distribution of some groundwater quality parameters in a coastal aquifer of Bosaso plain, Somalia, through using geostatistical approach, b) to make preliminary evaluations whether the groundwater resource unique in the area is suitable for drinking and irrigation uses. 


\section{Material and Methods}

\subsection{Study area}

Formerly known as Bandar Qasim, Bosaso is located Puntland state of Somalia on the Gulf of Aden coast, lies between Latitude $11^{\circ} 17^{\prime} \mathrm{N}$ and Longitude $49^{\circ} 11^{\prime} \mathrm{E}$ (Figure 1). Bosaso is the third largest city in the country and its population is estimated about 430,000 residents. Based on the Köppen-Geiger climate classification, the climate of the study area is arid type and has a hot desert climate (Rubel \& Kottek 2010). Furthermore, the city annually receives very little rainfall, on average, less than $50 \mathrm{~mm} \mathrm{year}^{-1}$. Groundwater is the primary source of drinking water for the services sector and irrigation water for agricultural sector.

Bosaso plain is a wide plain (approximately $70 \mathrm{~km}^{2}$ area) having a triangular shape. Depths of groundwater wells are subject to change, varying between 1 to $100 \mathrm{~m}$. The deepest water table, i.e. maximum depth of groundwater from soil surface, is $51.6 \mathrm{~m}$ in the south-eastern part of the plain. However, depth-to-watertable is minimum $(3 \mathrm{~m})$ in the northern coastline and zero at the interface between land and ocean surface. General groundwater flow direction is from south to north, towards the ocean.

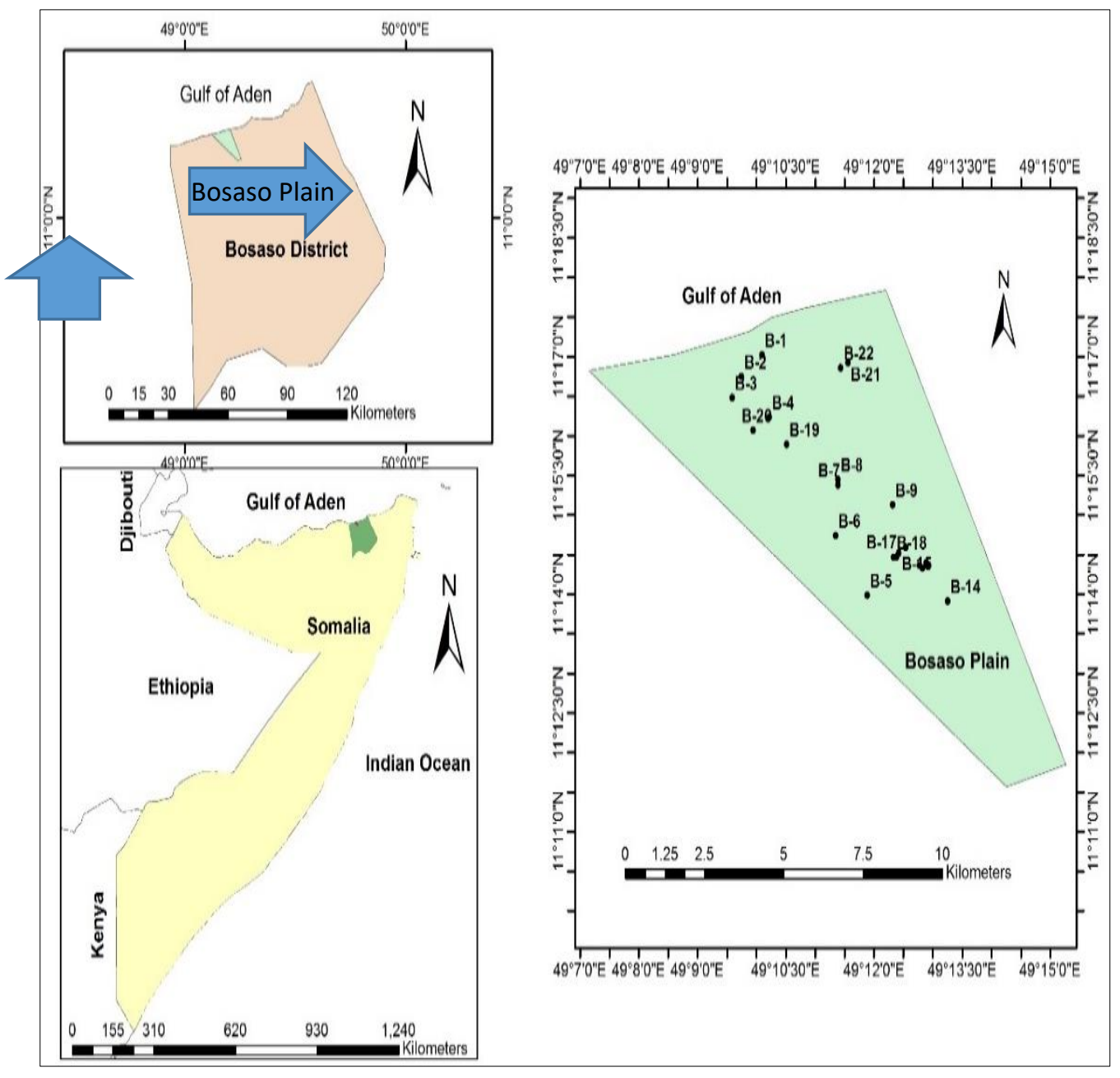

Figure 1- Location map of the study area and spatial distribution of groundwater wells (sampling points)

\subsection{Data}

Groundwater sampling locations were spatially distributed to cover the entire study area. Water samples were collected from groundwater wells in the study area in July of 2018. A total of 22 groundwater wells was visited. Location of sampling sites was determined by utilizing a hand-held Garmin GPS device. The collected water samples were returned to the water quality laboratory of Department of Agricultural Structures and Irrigation in Adana, Turkey, within four days. Groundwater quality parameters such as $\mathrm{pH}$, electrical conductivity $\left(\mathrm{EC}, \mathrm{dS} \mathrm{m} \mathrm{m}^{-1}\right.$ ), total dissolved solids (TDS, $\mathrm{mg} \mathrm{L}^{-1}$ ), sodium $\left(\mathrm{Na}, \mathrm{meq} \mathrm{L}^{-1}\right)$, chloride $\left(\mathrm{Cl}\right.$, meq $\left.\mathrm{L}^{-1}\right)$, calcium $\left(\mathrm{Ca}\right.$, meq $\left.\mathrm{L}^{-1}\right)$ and magnesium $\left(\mathrm{Mg}\right.$, meq $\left.\mathrm{L}^{-1}\right)$ were determined in the lab. Based on Ayers \& Westcot (1994), TDS was calculated by using chemical analysis results of $\mathrm{Na}, \mathrm{K}, \mathrm{Ca}, \mathrm{Mg}, \mathrm{Cl}, \mathrm{CO}_{3}, \mathrm{HCO}_{3}, \mathrm{SO}_{4}$ ions in the unit of $\mathrm{mg} \mathrm{L}^{-1}$. Additionally, following the procedures given in Fetter et al. (2017), sodium adsorption ratio (SAR) was calculated for each water sampling location by using $\mathrm{Na}, \mathrm{Ca}$ and $\mathrm{Mg}$ analysis results in meq $\mathrm{L}^{-1}$ unit. 


\subsection{Geostatistical methods}

In this study, we adopted semivariogram models for determining the spatial dependence structure of groundwater parameters and ordinary kriging (OK) estimation technique for mapping the variables considered. Kriging interpolation is known as the best linear unbiased estimation technique (BLUE). In this regard, it is an objective mapping technique by allowing the user to make optimal spatial interpolations at unsampled, i.e. unvisited, locations (Cetin \& Kirda 2003). The OK techniques are well documented in the latest literature (Masoud 2014; Sheikhy Narany et al. 2014). One of the main benefits of kriging estimation method is that it might be able to provide the user with the interpolation error, i.e. kriging estimation error, of the value s of the regionalized variable where there are no initial measurements. This feature provides a measure of the estimation accuracy and reliability of the spatial distribution of the variable (Yunsel et al. 2002; Theodossiou \& Latinopoulos 2006). The step-by-step procedure for ordinary kriging application is given in Figure 2.

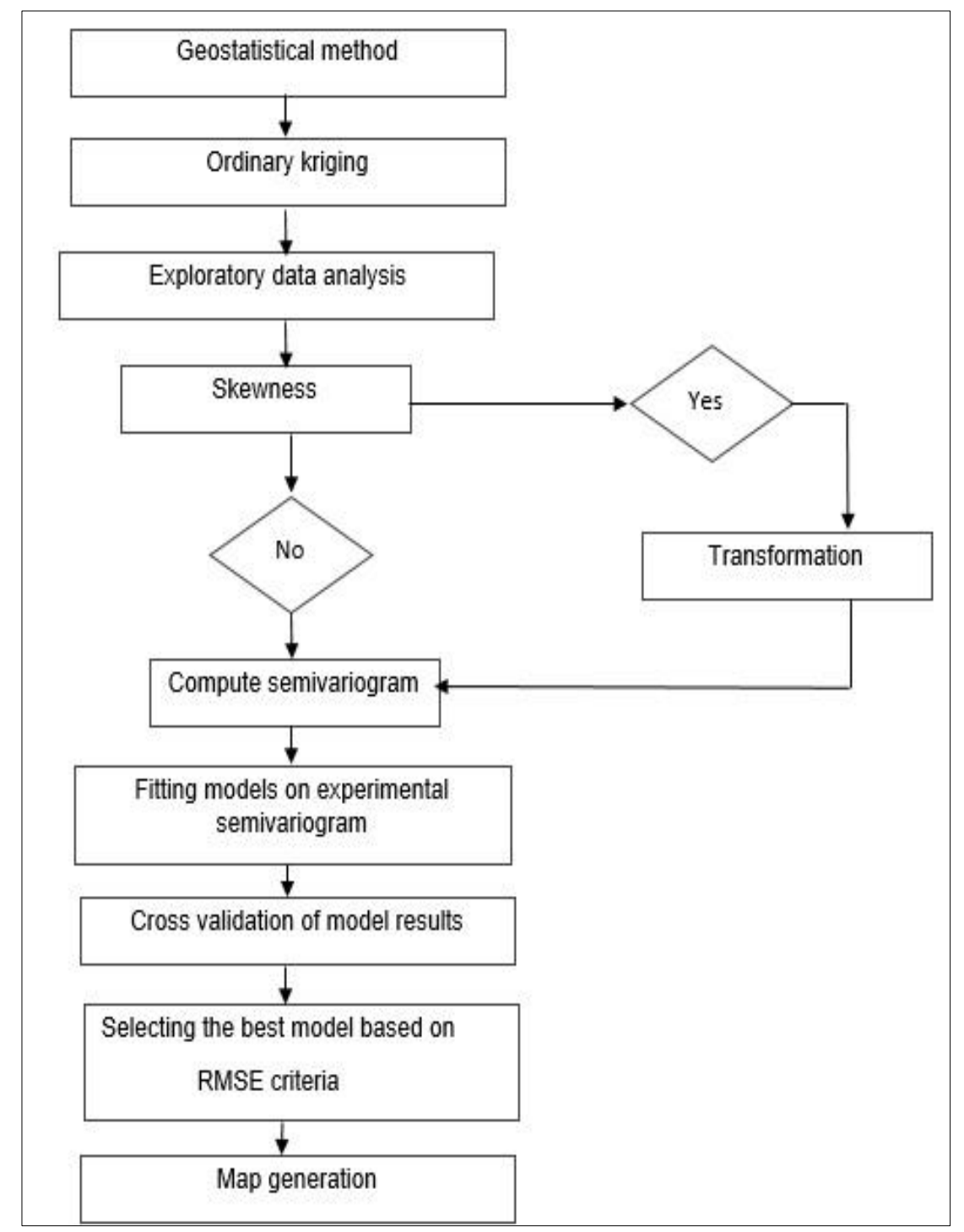

Figure 2- Flow chart of the procedure for ordinary kriging analaysis

The geostatistical modelling approach of kriging known as spatial interpolation technique (Clark \& Harper 2007; Cetin \& Kirda 2003) was adopted and, in turn, the semivariance structure of each water quality parameter was obtained by calculating experimental semivariogram values (Equation 1).

$\hat{\gamma}(h)=\frac{1}{2 N_{h}} \sum_{i=1}^{N_{h}}\left(g_{i}-g_{i+1}\right)^{2}$

Where; $h$ stands for the separation vector, i.e. distance between pairs of observations; $\hat{\gamma}(h)$ is the calculated value of the semivariogram, i.e. semi-variance, for $h ; N_{h}$ is the total number of pairs separated by $h ; g_{i}$ and $g_{i+1}$ are values of the variable " $g$ " at the point $x_{i}$ and at a point of distance $h$ from the point $x_{i+1}$. Theoretical semivariogram models and respective parameters were determined by applying methodology given in Figure 2. 


\section{Results and Discussion}

In this study, some of the water quality parameters were used to evaluate if groundwater is suitable for drinking and irrigation uses, or not. Groundwater samples have been classified based on drinking water quality standards given by WHO (2008). Due to the fact that groundwater wells have been utilized for irrigation in the region, suitability of groundwaters for irrigation purposes have been assessed on the basis of SAR and EC by adapting the standard procedures given in Richards (1954), Ayers \& Westcot (1994). Therefore, groundwater quality parameters consisting of pH, EC, TDS, Na, Cl, and SAR were obtained from the laboratory analysis. Practical information derived from the interpretation of results was, in turn, discussed below.

\subsection{Geostatistical analysis results}

Conventional statistical analysis has been carried out to check the normality of data because the kriging interpolation method gives best prediction when data are normally distributed. As seen from the descriptive statistics given in Table 1 , only pH data agree with the assumption of normality, and all the other parameters are characterized by a right-skewed distribution. Distribution of skewed data might be rendered symmetrical by using a 3-parameter lognormal (LN3) probability distribution function. The descriptive statistics of data sets and the transformation method was given in Table 1.

Table 1- Descriptive statistics of groundwater quality parameters

\begin{tabular}{lllllll}
\hline Statistics & $\mathrm{pH}$ & $\mathrm{EC}\left(\mathrm{dS} \mathrm{m} \mathrm{m}^{-1}\right)$ & $\mathrm{TDS}\left(\mathrm{mg} \mathrm{L}^{-1}\right)$ & $\mathrm{SAR}\left(\mathrm{meq} \mathrm{L}^{-1}\right)^{0.5}$ & $\mathrm{Cl}\left(\mathrm{mg} \mathrm{L}^{-1}\right)$ & $\mathrm{Na}\left(\mathrm{mg} \mathrm{L}^{-1}\right)$ \\
\hline $\mathrm{N}$ & 22 & 22 & 22 & 22 & 22 & 22 \\
$\mathrm{Min}$ & 7.03 & 1.44 & 1035.3 & 1.42 & 149.74 & 82.22 \\
Max & 8.00 & 16.50 & 10083.5 & 15.40 & 4502.40 & 2172.1 \\
Mean & 7.42 & 3.91 & 2665.4 & 4.09 & 775.51 & 404.69 \\
Median & 7.33 & 2.02 & 1427.3 & 2.07 & 273.65 & 145.56 \\
$\mathrm{SD}$ & 0.25 & 3.67 & 2357.0 & 3.98 & 1022.50 & 533.32 \\
$\mathrm{CV}(\%)$ & 3 & 94 & 88 & 97 & 132 & 132 \\
Skewness & 0.86 & 2.22 & 1.87 & 1.74 & 2.61 & 2.18 \\
Kurtosis & 0.25 & 5.79 & 3.53 & 2.35 & 8.09 & 4.98 \\
Transformation & Normal & 3 -parameter lognormal & & & \\
\hline
\end{tabular}

Semivariogram analysis was carried out in the ArcGIS platform by using "Geostatistical Analyst Tool". In order to obtain experimental semivariograms for each variable, Euclidian distances between observation pairs were calculated at the very beginning of the geostatistical analysis. Consequently, geographical coordinates of observation wells were transferred to Universal Transverse Mercator (UTM) coordinate system for rendering possible distance calculations. Then, experimental semivariograms have been obtained for each variable; hence, seven candidate experimental semivariogram models (Gaussian, Spherical, Circular, Exponential, Tetraspherical, Pentaspherical, Hole effect) and their parameters were determined and goodness-of-fit tests of each model have performed accordingly. The best fitted theoretical semivariogram model for each variable or groundwater quality parameter was chosen based on the lowest value of RMSE. Figure 3 shows omni-directional experimental semivariogram data points (semivariogram cloud) around the theoretical semivariogram model (solid line in blue color). Table 2 illustrates best-fitted theoretical semivariogram models and their fixed model parameters after conducting the cross-validation checks. After fixing the theoretical model and its parameters for each variable of interest, kriging maps of groundwater quality variables were generated by performing ordinary kriging interpolation technique. Based on the semivariogram analysis results, our conclusion was that all groundwater quality parameters were spatial dependent; therefore, range of influence varied between 1100 and $1950 \mathrm{~m}$ as seen in Table 2 as well as in Figure 3.

Table 2- Best-fitted semivariogram models and their estimated parameters for the transformed data, i.e. LN3, except for pH

\begin{tabular}{llllll}
\hline Parameters & $\begin{array}{l}\text { Semivariogram } \\
\text { Model }\end{array}$ & $\begin{array}{l}\text { Nugget } \\
\left(\mathrm{C}_{0}\right)\end{array}$ & $\begin{array}{l}\text { Sill } \\
\left(\mathrm{C}_{0}+\mathrm{C}\right)\end{array}$ & Range $(\mathrm{m})$ & RMSE \\
\hline $\mathrm{pH}$ & Hole effect & 0.0002 & 0.0005 & 1131.5 & 0.242 \\
$\mathrm{EC}\left(\mathrm{dS} \mathrm{m}^{-1}\right)$ & Exponential & 0.0000 & 0.2803 & 1893.9 & 3.539 \\
$\mathrm{TDS}\left(\mathrm{mg} \mathrm{L}^{-1}\right)$ & Exponential & 0.0000 & 0.2800 & 1948.9 & 2272.495 \\
$\mathrm{SAR}\left(\mathrm{meq} \mathrm{L}^{-1}\right)^{0.5}$ & Exponential & 0.0000 & 0.3159 & 1840.0 & 3.654 \\
$\mathrm{Cl}\left(\mathrm{mg} \mathrm{L}^{-1}\right)$ & Hole effect & 0.0646 & 0.4580 & 1678.1 & 1013.851 \\
$\mathrm{Na}\left(\mathrm{mg} \mathrm{L}^{-1}\right)$ & Exponential & 0.0000 & 0.5835 & 1858.1 & 520.058 \\
\hline
\end{tabular}




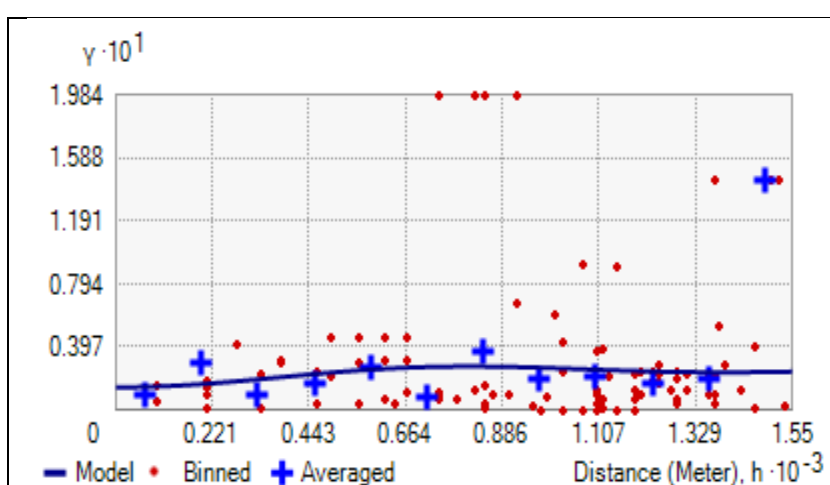

(a)

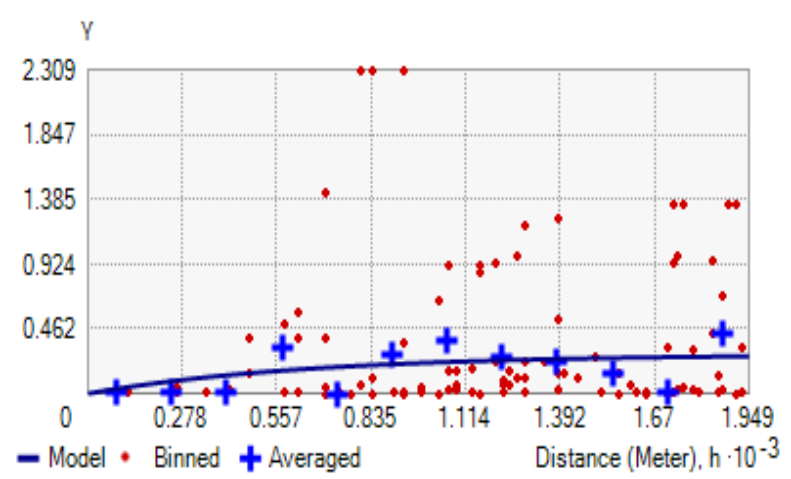

(c)

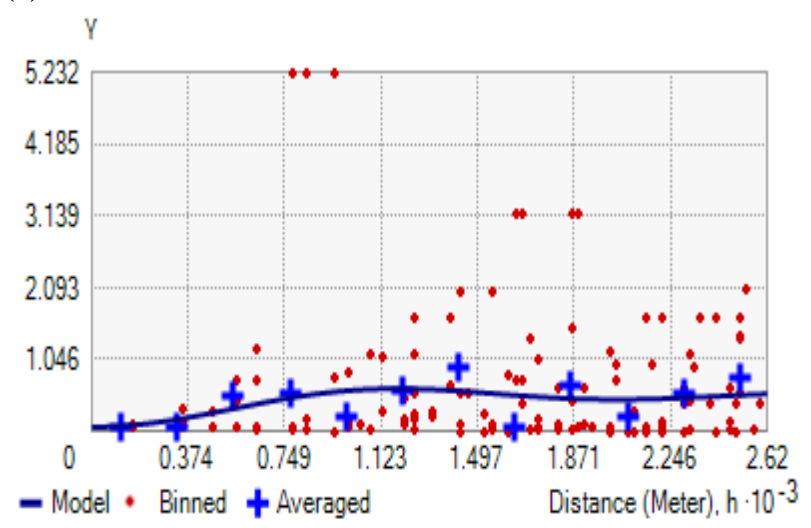

(e)

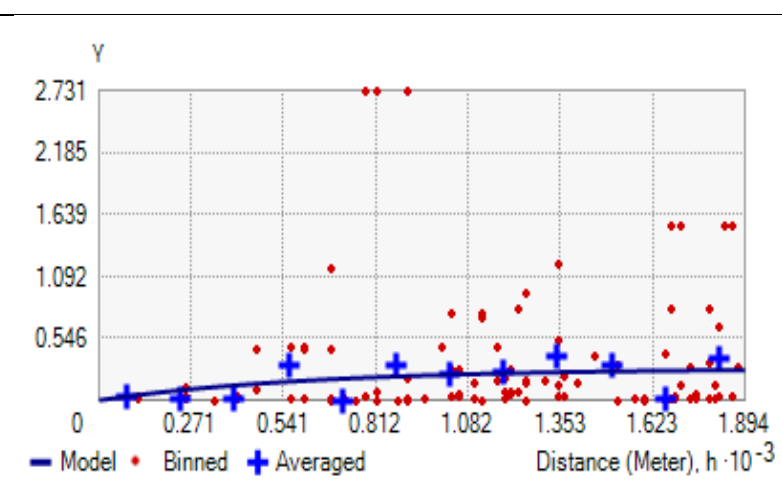

(b)

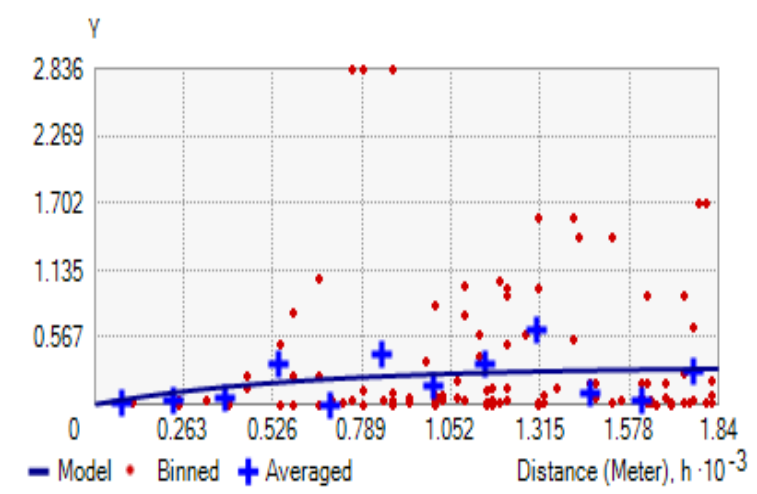

(d)

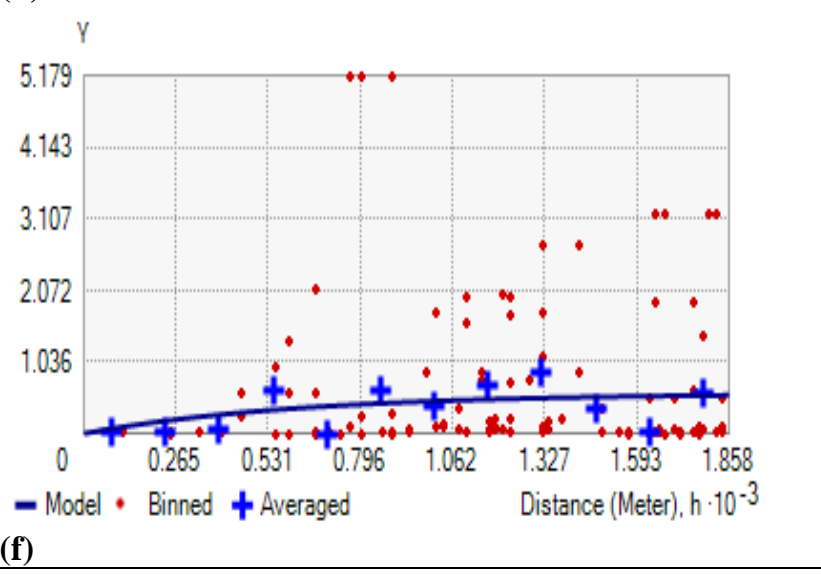

Figure 3- Best fitted semivariogram models; (a) pH, (b) electrical conductivity (EC), (c) total dissolved solids (TDS), (d) sodium adsorption ratio (SAR), (e) chloride ( $\mathrm{Cl}$ ), and (f) sodium (Na). Easting and northing stand for distance between sample pairs and semivariance value of the variable considered, respectively

\subsection{Groundwater quality assesment for drinking water}

\subsubsection{Changes in $\mathrm{pH}$}

$\mathrm{pH}$ is an important indicator of water that is changing chemically. Not only does the $\mathrm{pH}$ of a stream affect organisms living in the water, but also a changing $\mathrm{pH}$ in a stream can be an indicator of increasing pollution or some other environmental factors. This is also true for groundwater. In this study, $\mathrm{pH}$ values of groundwater samples ranged from 7.03 to 8.00 as shown Figure $4 \mathrm{a}$, indicating alkaline conditions in the groundwater system. Geology of the Bosaso plain corroborates alkaline character of the aquifer system. Additionally, $\mathrm{pH}$ data for the variables clearly revealed that the groundwater in Bosaso plain was within limits of pH range 6.5-8.5 as specified by WHO (2008). Based on WHO standards, it could be concluded that groundwater in the study site met the drinking water quality requirements with regard to $\mathrm{pH}$.

\subsubsection{Electrical conductivity}

Electrical conductivity (EC) is a measure of water potential to deliver an electric current. The higher the salinity concentrations of water are, the higher EC is expected if measured. Pursuant thereto, EC values were found to be higher than $1.5 \mathrm{dS}^{-1}$ except for three samples, and groundwater was classified as saline water according to Langenegger (1990). In line with WHO 
standards for drinking water, the maximum allowable limit of EC is $1.5 \mathrm{dS} \mathrm{m}^{-1}$. Spatial distribution map of EC (Figure $4 \mathrm{~b}$ ) shows that EC is increasing from south-east inland to the northern coastline of the study area. According to WHO standards, most of the groundwater samples are above the permissible EC limit with the highest value of $16.51 \mathrm{dS} \mathrm{m}^{-1}$. As seen in Figure $4 \mathrm{~b}$, EC of groundwater is remarkably increasing while approaching the shoreline. Substantial rises in EC values shorewards may be a clear indication of seawater intrusion into coastal aquifers of the study area. It could be concluded that areas stretching along the shore are potentially subject to severe salinization risk.

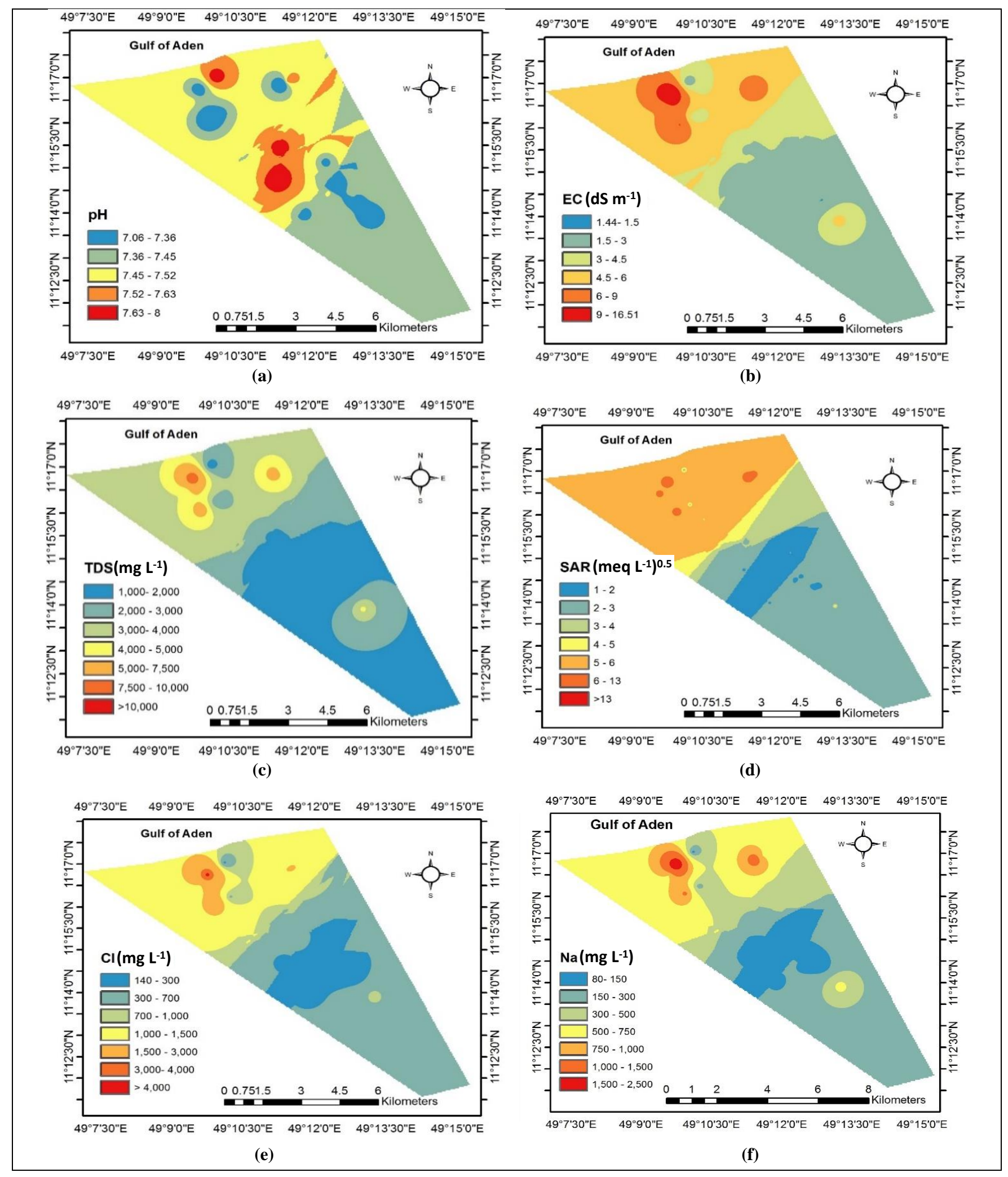

Figure 4- Spatial distribution map of analyzed groundwater parameters in Bosaso plain: (a) pH, (b) electrical conductivity (EC), (c) total dissolved solids (TDS), (d) sodium adsorption ratio (SAR), (e) chloride (CI), and (f) sodium (Na) 


\subsubsection{Total dissolved solids}

Total dissolved solids (TDS) contain inorganic salts such as potassium, magnesium, calcium, sodium, bicarbonates, sulfates and chlorides and some small quantities of organic matter. The values of TDS in groundwater in the study area varied from $1035.3 \mathrm{mg} \mathrm{L}^{-1}$ to $10,083.5 \mathrm{mg} \mathrm{L}^{-1}$, revealing a very high and dominant salinization problem in some specific locations in the study area. As stated by WHO standards, the acceptable level limit of TDS for drinking water is $500 \mathrm{mg} \mathrm{L}^{-1}$. In this respect, all TDS concentrations in the study area exceed the acceptable limit, indicating the salinization pressure. On the other hand, based on WHO standards, the maximum allowable amount of TDS is $1500 \mathrm{mg} \mathrm{L}^{-1}$. TDS map in Figure 4c shows that total dissolved solids in the central part of the study area are within the maximum allowable amount. But in the north, TDS is above the maximum allowable amount. It is globally postulated that coastal aquifers, like Bosaso Plain, are under the risk of seawater intrusion, i.e. water quality deterioration. However, seawater intrusion was corroborated with the EC, SAR, TDS, $\mathrm{Cl}$ and $\mathrm{Na}$ distribution maps. It is important to emphasize that the relationship between EC and TDS is rather high as seen in Figure 4b and $4 \mathrm{c}$. On the other hand, regression analysis revealed that the relationship was in the form of linear $\left[T D S\left(m g L^{-1}\right)=\right.$ $\left.659.72 * E C\left(d S \mathrm{~m}^{-1}\right)\right]$ and statistically significant $\left(R^{2}=0.972\right)$. Our conclusion was that this type of mathematical relationship can be used confidently in practice for estimation of TDS from precise EC measurements in the field.

\subsubsection{Chloride}

The source of chloride in groundwater is both natural and anthropogenic, such as run-off containing road deicing salts, the use of inorganic fertilizers, landfill leachates, septic tank effluents, animal feeds, industrial effluents, irrigation and drainage waters, and seawater intrusion in coastal areas (Karanth 1987). Chloride concentration increases when mineral content increases (Sawyer et al. 2002). The chloride ion concentration in fresh waters is fairly low and typically less than $100 \mathrm{mg} \mathrm{L}^{-1}$, except for brackish or saline waters (Fetter et al. 2017). Higher chloride concentrations in drinking water may cause cardiovascular disease and blood pressure (McCallum et al. 2015). Therefore, the chloride concentrations of groundwaters in the urban coastal aquifer of Bosaso plain needs determining due to the fact that the aquifer is a source of drinking water for the local community. Chloride concentrations of groundwater samples collected in this study varied from 149.74 to $4502.4 \mathrm{mg} \mathrm{L}^{-1}$ as seen in Table 1. The highest concentration of chloride is witnessed to be in the north along the coastline. $\mathrm{Cl}$ concentrations are higher than the maximum allowable limits by WHO standards $\left(250 \mathrm{mg} \mathrm{L}^{-1}\right)$ as shown in Figure 4e. The closer to the sea is, the higher $\mathrm{Cl}$ concentration is in the groundwater body. The increasing trend in $\mathrm{Cl}$ concentration towards the sea may be an apparent indication of seawater intrusion to the coastal aquifer in use. Likewise, the spatial distribution of Na concentration supported the postulate of seawater intrusion in the study site.

\subsubsection{Sodium}

All groundwater samples contain sodium element to some extent because most rocks and soils naturally contain sodium compounds. The origin of sodium in groundwater may be from varied sources such as the erosion of salt deposits and sodium bearing rock minerals. As a matter of fact, over-exploitation of the coastal aquifer can lead a lateral movement of seawater into freshwater body (Hem 1985), causing to increase of sodium concentrations remarkably. High sodium contamination in drinking waters is quite risky, for high sodium in drinking water can cause higher systolic and diastolic blood pressure (Hallenback et al. 1981). In this study, the aquifer is contiguous to the sea, and the area is almost flat with a slope of less than $0.6 \%$, on the average. Sodium concentration map in Figure $4 \mathrm{f}$ shows an increasing trend in the concentrations from the southeast to the north. Sodium concentrations in the northern parts of the study area exceed the maximum permissible limit of $250 \mathrm{mg} \mathrm{L}^{-1}$ indicated by WHO and groundwater with $\mathrm{Na}$ concentrations higher than $250 \mathrm{mg} \mathrm{L}^{-1}$ is not safe for drinking purposes. It is important to emphasize that the variability in sodium concentrations are extremely high (CV>130\%), revealing the evidence of seawater intrusion into the aquifer. On the other hand, spatial distribution of EC, TDS, SAR, Cl and Na shows that interpolated values by the shore increase remarkably. This might be attributed to the effect of seawater intrusion, too. Therefore, groundwater abstraction strategy should consider the seawater intrusion issue and degradation in groundwater quality, which jeopardize the sustainable use of urban coastal groundwater aquifer in the future.

\subsection{Groundwater quality assessment for irrigation water supply}

Electrical conductivity (EC) and the sodium adsorption ration (SAR) of any source of water are among the most widely used irrigation water quality parameters (Appelo \& Postma 2005). However, Ayers \& Westcot (1994) points out that some specific ionic composition of water is of great importance regarding irrigation water quality standards. On the other hand, SAR indicates the effect of relative cation concentration on sodium hazard and its accumulation in the soil. SAR is a more reliable method (Richards 1954) for determining the suitability of water for irrigation purposes. SAR gives a very good assessment of water quality of irrigation uses with respect to sodium hazard, since it is more closely related to exchangeable sodium percentages (Tiwari \& Manzoor 1988). Hence, SAR is calculated using the following formula (Equation 2):

$S A R=\frac{N a}{\sqrt{\frac{C a+M g}{2}}}$ 
Where; concentrations are in the unit of meq $\mathrm{L}^{-1}$.

Some descriptive statistics of SAR values were given in Table 1. As seen from Table 1, SAR values were characterized with a right-skewed distribution and rather high variability $(\mathrm{CV}=97 \%)$. Therefore, SAR values in the study area varied from 1.42 to $\left.15.40(\mathrm{meq} \mathrm{L})^{-1}\right)^{0.5}$ as shown in the Figure 4d. Nevertheless, SAR values of all samples were found to be less than 10 (meq $\left.\mathrm{L}^{-1}\right)^{0.5}$ except two samples and were classified as excellent in terms of irrigation water quality standards according to Todd (1980) and Richards (1954). However, the permissible value of SAR in irrigation waters is $13\left(\mathrm{meq} \mathrm{L}^{-1}\right)^{0.5}$. If the permissible level of SAR is considered, it is clear from the Figure $4 \mathrm{~d}$ that some parts of the study area contiguous to the sea is under the risk of sodium hazard. Farmers leaving in those areas should pay attention to sodium hazard risk to the crops and soils as well. On the other hand, as seen clearly from Table 1, minimum, mean and maximum EC of groundwater is $1.44,3.91$ and $16.5 \mathrm{dS} \mathrm{m}^{-1}$, respectively. The salinity of groundwater samples in the area was found to be beyond the usual rage, i.e. $0<\mathrm{EC}<3 \mathrm{dS} \mathrm{m}^{-1}$ and $0<\mathrm{TDS}<2000 \mathrm{mg} \mathrm{L}^{-1}$ (Ayers \& Westcot 1994) in irrigation waters. Based on permissible salinity levels in terms of irrigation, we have enough evidence to conclude that majority of groundwater wells in the study area are rather risky to the agricultural crops based on the irrigation water quality criteria given in Ayers \& Westcot (1994).

Richards (1954), Todd (1980) and many others, e.g. Appelo \& Postma (2005), noted several advantages of joint evaluations of SAR and EC values on a graph, apart from individual assessments. And consequently, groundwaters in the study area were assessed according to the US Salinity Laboratory (USSL) classification (Richards 1954) by plotting groundwater salinity (EC) data against SAR values (Figure 5). Surprisingly, graphical results indicated that $68 \%$ of water samples fell within the C3S1 and C4S1 categories/classes -low risk of sodium hazard associated with high and very high salinity hazard, respectively-and only $9 \%$ fell into the C4S2 class-appreciable sodium hazard particularly in fine textured soils associated with very high salinity hazard, i.e. not suitable for irrigation under ordinary conditions, albeit used presently- as shown in Figure 5. This groundwater of poor quality is in turn suitable only for high salt-tolerant crops. Results further indicated that $23 \%$ of water samples, belonging to category $\mathrm{C} 4 \mathrm{~S} 3$ and $\mathrm{C} 4 \mathrm{~S} 4$, were generally not suitable for irrigation due to poor water quality associated with high salinity as well as high sodium hazard risk. Therefore, farmers in the area must restrict themselves to adopt modern irrigation methods such as drip irrigation and subsurface irrigation in the area in order to prevent crops and soils from salinization risk or salinity hazard as well as sodium injury for sustainable agriculture.

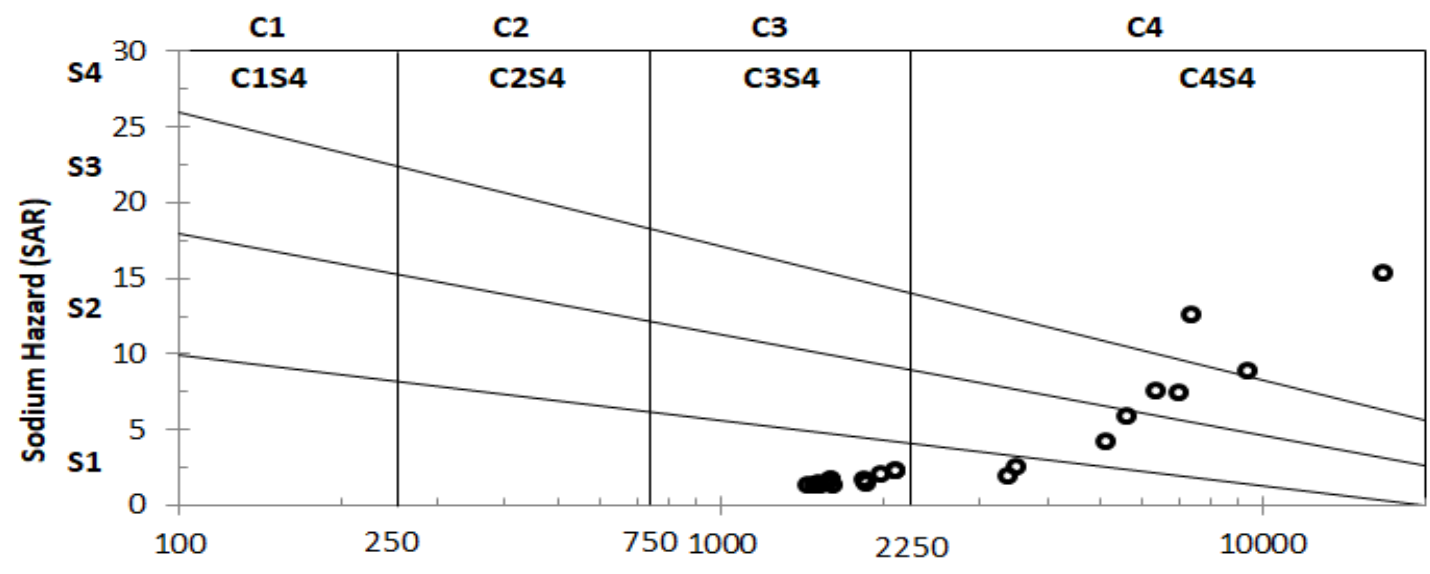

Salinity Hazard (Electrical conductivity (EC, $\left.\mu \mathrm{mhos} \mathrm{cm}^{-1}\right)$ )

Figure 5- Classification of groundwater samples by US Salinity Laboratory diagram

\section{Conclusions}

Groundwater resources are essential for drinking water supply of Bosaso city. Ordinary kriging was utilized to map the spatial distribution of groundwater quality parameters. The study illustrated that the kriging method was a useful tool for delineating the spatial distribution of the groundwater quality parameters. According to the drinking water standards, results showed that the most of groundwaters in the study area was unsafe for drinking purposes, except in the central area (Biyo Kulule) where municipal water supply was located. As regards to irrigation uses, the very minor area may be under the risk of alkalinity or sodium hazard. However, half of the study area is under the salinization risk, not suitable for irrigation, except for high salttolerant crops/vegetation. Spatial distribution of groundwater quality maps reveals that quality decreases from the southeast to the north (coastline) of the plain. Research findings indicated that the Bosaso aquifer has been affected by seawater intrusion due to the over groundwater extraction. Therefore, we are recommending to be closed all wells located in the contaminated areas especially in the northwest (Balade) to avoid further groundwater degradation by seawater intrusion. Currently, the groundwater quality in the study area has not been monitored. Therefore, this study will assist the water authority for taking appropriate measures in order to maintain efficient groundwater exploitation and management plans in Bosaso plain. Our final 
concrete conclusion is that further research is needed in this area to figure out the extent of seawater intrusion and develop seawater intrusion model. In turn, monitoring of groundwater depths and quality parameters has been highly recommended for the sake of reliable future studies.

\section{Acknowledgements}

The authors would like to acknowledge Puntland State Agency for Water Energy and Natural Resources (PSAWEN), Bossaso Water Supply (GUMCO) in Somalia for providing an access and support during data collection. The authors are grateful to the Cukurova University, Faculty of Agriculture, Department of Agricultural Structures and Irrigation in Adana, Turkey, for permission to use water quality laboratory. We would also like to extend our special thanks to the technicians of the laboratory for their help during water quality analysis.

\section{References}

Appelo C A J \& Postma D (2005). Geochemistry Groundwater and Pollution. $2^{\text {nd }}$ Edition, A. A. Balkema Publishers, Rotterdam, the Netherlands, pp. 634

Arslan H (2012). Spatial and temporal mapping of groundwater salinity using ordinary kriging and indicator kriging: The case of Bafra Plain, Turkey. Agricultural Water Managemen 113: 57-63, DOI: 10.1016/j.agwat.2012.06.015

Ayers R S \& Westcot D W (1994). Water for griculture. FAO Irrigation and Drainage Paper 29. Revision 1: 1-130

Cetin M \& Kirda C (2003). Spatial and Temporal Changes of Soil Salinity in a Cotton Field Irrigated with Low-quality Water. Journal of Hydrology 272: 238-249

Clark I \& Harper W (2007). Practical Geostatistics 2000. Alloa, Scotland: Geostokos (Ecosse)

Fetter C W, Boving T \& Kreamer D (2017). Contaminant Hydrogeology. $3^{\text {rd }}$ Edition, Waveland press, Inc., Illinois, pp. 647

Goovaerts P, AvRuskin G, Meliker J, Slotnick M, Jacquez G \& Nriagu J (2005). Geostatistical modeling of the spatial variability of arsenic in groundwater of southeast Michigan. Water Resources Research, 41, W07013, DOI:10.1029/2004WR003705

Hallenback W, Brenniman G \& Anderson R (1981). High sodium in drinking water and its effect on blood pressure. American Journal of Epidemiology, 114(6): 817-826

Hem J D (1985). Study and interpretation of chemical characteristics of natural water. US Geological Survey, Water Supply Paper No. 2254

Karanth K R (1987). Groundwater Assessment, Development and Management. Tata McGraw-Hill, New Delhi, pp. 720

Langenegger O (1990). Groundwater quality in rural areas of western Africa. UNDP project INT/81/026:10

Masoud A A (2014). Groundwater quality assessment of the shallow aquifers west of the Nile Delta (Egypt) using multivariate statistical and geostatistical techniques. Journal of African Earth Sciences 95:123-137, DOI: $10.1016 /$ j.jafrearsci.2014.03.006

McCallum L, Lip S \& Padmanabhan S (2015). The hidden hand of chloride in hypertension. Pflügers Archiv. European Journal of Physiology 467(3): 595-603, DOI: 10.1007/s00424-015-1690-8

Nas B \& Berktay A (2008). Groundwater quality mapping in urban groundwater using GIS. Environmental Monitoring and Assessment 160(1-4): 215-227, DOI: 10.1007/s10661-008-0689-4

Nur A, Ishaku J \& Yusuf S (2012). Groundwater Flow Patterns and Hydrochemical Facies Distribution Using Geographical Information System (GIS) in Damaturu, Northeast Nigeria. International Journal of Geosciences 03(05): 1096-1106, DOI: $10.4236 /$ ijg.2012.35111

Richards L A (1954). Diagnosis and improving of saline and alkali soils. United States Department of Agriculture, Hand Book 60, Washington DC, USA

Rubel F \& Kottek M (2010). Observed and projected climate shifts 1901-2100 depicted by world maps of the Köppen-Geiger climate classification. Meteorologische Zeitschrift 19: 135-141. DOI: 10.1127/0941-2948/2010/0430

Said A A, Cetin M \& Yurtal R (2019). Drought assessment and monitoring using some drought indicators in the semi-arid Puntland State of Somalia. Fresenius Environmental Bulletin 28,11A: 8765-8772

Sarath Prasanth S V, Magesh N, Jitheshlal K, Chandrasekar N \& Gangadhar K (2012). Evaluation of groundwater quality and its suitability for drinking and agricultural use in the coastal stretch of Alappuzha District, Kerala, India. Applied Water Science 2(3): 165-175

Sawyer C N, Mccarty P L \& Parkin G F (2002). Chemistry for Environmental Engineering. The McGraw-Hill Companies, Inc., Newyork, pp. 752

Shamsudduha M (2007). Spatial variability and prediction modeling of groundwater arsenic distributions in the shallowest alluvial aquifers in Bangladesh. Journal of Spatial Hydrology 7(2): 33-46, DOI: 10.1007/s12517-018-3430-9

Sheikhy Narany T, Ramli M, Aris A, Sulaiman W \& Fakharian K (2014). Groundwater irrigation quality mapping using geostatistical techniques in Amol-Babol Plain, Iran. Arabian Journal of Geosciences 8(2): 961-976, DOI: 10.1007/s12517014-1271-8

Theodossiou N \& Latinopoulos P (2006). Evaluation and optimisation of groundwater observation networks using the Kriging methodology. Environmental Modelling \& Software 21(7): 991-1000, DOI: 10.1016/j.envsoft.2006.07.001

Tiwari T N \& Manzoor A (1988). River pollution in Kathmandu valley (Nepal) suitability of river water for irrigation. Indian Journal of Environmental Protection 8(4): 269-274 
Todd D K (1980). Groundwater Hydrology. 2nd Edition, John Wiley and Sons, Inc., New York, pp. 535

WHO (2008). Guidelines for drinking-water quality. $3^{\text {rd }}$ Edition, World Health Organization, Geneva, pp. 515

Yunsel T, Ersoy A \& Cetin M (2002). Geostatistical analysis of spatial distribution of salt bed thicknesses. Journal of Mining Science 38(6): 565-573

Zehtabian G, Azareh A, Samani A N \& Rafei J (2013). Determining the most suitable geostatistical method to develop zoning map of parameters EC, TDS and TH groundwater (case study: Garmsar Plain, Iran). International Journal of Agronomy and Plant Production 4: 1855-186 